\title{
触 New Disease Reports \\ First report of hard watermelon syndrome in Tunisia associated with Tomato yellow leaf curl virus infection
}

M. Mnari-Hattab*, S. Zammouri and M.R. Hajlaoui

Laboratoire de Biotechnologie Appliquée à l'Agriculture, INRA Tunisie, Université de Carthage, 2049 Ariana, Tunisie

*E-mail: hattab.monia@iresa.agrinet.tn

Received: 20 Jul 2014. Published: 18 Aug 2014.

In Tunisia, watermelon (Citrullus lanatus) is one of the most common and popular summer fruit crops, and is widely cultivated in the central and southern parts of the country. Since 1994, abnormal symptoms have been observed on fruits by the end of the cropping season grown in the regions of Kairouan, Sidi Bouzid and Gafsa. In some fields, watermelons harden precociously and, when ripe, present a white heart. Moreover, young leaves were mildly curled and stunted (Fig. 1). These symptoms were distributed randomly in the fields and were initially misdiagnosed and attributed to physiological and nutritional disorders.

Since the first reports of this syndrome in 1994, leaf and fruit samples with characteristic symptoms had been tested for the occurrence of any of the viruses known to affect cucurbits in Tunisia, but none showed any positive results (Mnari-Hattab et al., 2009). The frequency and distribution of the 'hard watermelon syndrome' suggested that virus infection might be responsible, particularly as Tomato yellow leaf curl virus (TYLCV), Tomato yellow leaf curl Sardinia virus (TYLCSV) and/or parental recombinant genus Begomovirus (family Geminiviridae) were widespread on tomato and on silverleaf nightshade (Solanum elaeagnifoli) growing in the same area (Mnari-Hattab et al., 2014; Zammouri \& Mnari-Hattab, 2014).

In 2014, a total of 22 samples, eight samples of preserved vegetable material (i.e. leaves, peduncle and fruit bark) and 14 samples freshly collected from plants exhibiting the characteristic syndrome were tested for begomovirus infection. Genomic DNA was purified, and PCR amplification was performed using degenerate oligonucleotide primers based on the sequence in the Begomovirus coat protein genes (Wyatt \& Brown, 1996; Mnari-Hattab et al., 2014). Amplicons circa 560 bp in size were obtained from all the tested symptom-bearing samples (plants with hardened fruit) but no amplicons were generated from symptomless plan samples. Three of the amplicons were cloned and sequenced, and the nucleotide sequences were deposited in GenBank (Accession Nos KM042091 - KM042093). BLAST searches of the GenBank database revealed that the sequences from watermelon, which were 97.2 to $98.7 \%$ identical to one another other, shared $96 \%$ homology with a Turkish TYLCV isolate (Accession No. AJ867487). Similar TYLCV amplicons generated from tomato and silverleaf nightshade plants collected from open field tomato crops in Kairouan had similar sequences (results not shown). Further investigations using multiplex PCR amplification (Davino et al., 2008) revealed that all 22 samples referred to above were infected with TYLCV, and that two of the samples were doubly infected with TYLCV and TYLCSV following generation of respectively $570 \mathrm{bp}$ and $800 \mathrm{bp}$ amplicons for the two viruses. To the best of our knowledge, this is the first report that associates the watermelon hardness syndrome with Tomato yellow leaf curl virus infection. Based on our findings, further targeted surveys must therefore be undertaken to advance our knowledge on tomato yellow leaf curl disease epidemics on cucurbit crops in Tunisia.

\section{References}

Davino S, Davino M, Accotto GP, 2008. A single-tube PCR assay for detecting viruses and their recombinants that cause tomato yellow leaf curl disease in the Mediterranean basin. Journal of Virological Methods 147, 93-98.

Mnari-Hattab M, Gauthier N, Zouba A, 2009. Biological and molecular characterization of the Cucurbit aphid-borne yellows virus affecting cucurbits in Tunisia. Plant Disease 93, 1065-1072.

http://dx.doi.org/10.1094/PDIS-93-10-1065

Mnari-Hattab M, Zammouri S, Pellegrin F, Gauthier N, 2014. Natural occurrence of begomovirus recombinants associated with tomato yellow leaf curl disease co-existing with parental viruses in tomato crops and weeds in Tunisia. Journal of Plant Pathology 96, 195-200. http://dx.doi.org/10.4454/JPP.V96I1.043

Wyatt SD, Brown JK, 1996. Detection of subgroup III geminivirus isolates in leaf extracts by degenerate primers and polymerase chain reaction. Phytopathology 86, 1288-1293. http://dx.doi.org/10.1094/Phyto-86-1288

Zammouri S, Mnari-Hattab M, 2014.First report of Solanum elaeagnifolium as natural host of Tomato yellow leaf curl virus species (TYLCV and TYLCSV) in Tunisia. Journal of Plant Pathology 96, 434. http://dx.doi.org/10.4454/JPP.V96I2.008



Figure 1

To cite this report: Mnari-Hattab M, Zammouri S, Hajlaoui MR, 2014. First report of hard watermelon syndrome in Tunisia associated with Tomato yellow leaf curl virus infection. New Disease Reports 30, 7. http://dx.doi.org/10.5197/j.2044-0588.2014.030.007

(c) 2014 The Authors

This report was published on-line at www.ndrs.org.uk where high quality versions of the figures can be found. 